\title{
Lipoprotein Lipase Secretion by Human
}

\section{Monocyte-derived Macrophages}

\author{
Alan Chait, Per-Henrik Iverius, and John D. Brunzell, Division of \\ Metabolism and Endocrinology, Department of Medicine, University of \\ Washington, Seattle, Washington 98195
}

\begin{abstract}
A B S TRACT Human monocyte-derived macrophages in culture produced lipoprotein lipase. Although freshly isolated blood monocytes did not secrete much lipase activity, $1 \mathrm{~d}$ in culture was sufficient to trigger measureable enzyme production. During 3 wk in culture, maximal activity was attained after 7 d. At all times, the culture medium contained more enzyme activity than did a serum-heparin eluate or a detergent extract of the cell layer. The lipase activity was stimulated by serum and was inhibited by preincubation with antiserum to bovine lipoprotein lipase or when assayed at a high salt concentration. Furthermore, the enzyme bound to a heparin-Sepharose affinity column at physiological ionic strength. Cells cultured from a subject with primary lipoprotein lipase deficiency secreted no detectable enzyme. Since macrophages are prominent components of atherosclerotic lesions in man, their ability to synthesize and secrete lipoprotein lipase may be important to atherogenesis.
\end{abstract}

\section{INTRODUCTION}

Macrophages recently have received renewed attention in relation to their potential role in atherogenesis because they appear to be precursors of some arterial wall foam cells. The intracellular accumulation of lipid may be mediated by cell surface receptors that rec-

Dr. Chait is a recipient of U. S. Public Health Service Special Emphasis Career Award AM 00592.

Received for publication 5 September 1981 and in revised form 5 November 1981. ognize chemically modified lipoproteins $(1,2)$. Also, macrophages secrete a multitude of products (3), some of which may be important in atherogenesis (4). Zilversmit (5) has proposed that lipid accumulation in atherosclerotic lesions may be facilitated by the local production of lipoprotein lipase, which would transform triglyceride-rich lipoproteins into remnants that are small enough to enter the arterial wall (5). Therefore, the recent demonstration that macrophages of animal origin produce lipoprotein lipase (6) is of considerable interest. The present study was undertaken to determine whether macrophages of human origin also produce this enzyme.

\section{METHODS}

Subjects. Monocytes were obtained from two normal female volunteers (S.M. and C.M.) aged 27 and 26, respectively, and from a 31-yr-old male (R. S.) with primary lipoprotein lipase deficiency. This patient had no lipoprotein lipase activity either in his adipose tissue or plasma during an infusion of heparin (subject No. 4 in reference 7).

Isolation and culture of monocyte/macrophages. Monocytes were separated from whole blood by method B of Fogelman et al. (8). In brief, erythrocytes were removed by sedimentation in Plasmagel, after which the leukocytes in the supernatant plasma were separated by counterflow centrifugation in a Beckman J6 Elutriator rotor (Beckman Instruments, Inc., Palo Alto, Calif.). Cells from the late appearing monocyte enriched fractions were then centrifuged through Ficoll-Hypaque, yielding a preparation of monocytes that was $\sim 95 \%$ pure.

These cells either were used immediately for experiments, or were maintained in culture (9). For culture, monocytes were plated into $35-\mathrm{mm}$ plastic tissue culture dishes $\left(5 \times 10^{5}\right.$ cells/dish) in RPMI 1640 medium containing $20 \%$ autologous 
TABLE I

Lipoprotein Lipase Activity in Freshly Isolated Human Monocytes and Cultured Monocyte-derived Macrophages

\begin{tabular}{|c|c|c|c|c|c|c|c|}
\hline \multirow[b]{2}{*}{ Enzyme source } & \multirow[b]{2}{*}{ Subject } & \multicolumn{6}{|c|}{ Lipoprotein lipase activity ${ }^{\bullet}$} \\
\hline & & Day 0 & Day 1 & Day 4 & Day 7 & Day 14 & Day 21 \\
\hline & & $\begin{array}{c}\mathrm{nmol} / \mathrm{min} / \\
5 \times 10^{5} \mathrm{cells}\end{array}$ & & & $\mathrm{nmol} / \mathrm{min} / \mathrm{dis}$ & & \\
\hline \multirow[t]{3}{*}{ Culture medium } & Normal (S.M.) & - & $13.3 \pm 0.5$ & $33.6 \pm 0.6$ & $57.3 \pm 1.2$ & $49.7 \pm 0.8$ & $39.5 \pm 1.3$ \\
\hline & Normal (C.M.) & - & $12.0 \pm 0.2$ & $37.6 \pm 1.4$ & $57.7 \pm 2.5$ & $56.9 \pm 1.6$ & - \\
\hline & Patient (R.S.) & - & 0 & 0 & 0 & 0 & - \\
\hline \multirow[t]{3}{*}{ Heparin eluate } & Normal (S.M.) & 0 & $2.4 \pm 0.2$ & $2.7 \pm 0.1$ & $6.7 \pm 0.3$ & $3.9 \pm 0.1$ & $4.2 \pm 0.1$ \\
\hline & Normal (C.M.) & $0.5 \pm 0.2$ & $1.5 \pm 0.1$ & $1.4 \pm 0$ & $6.6 \pm 0.1$ & $4.9 \pm 0.2$ & - \\
\hline & Patient (R.S.) & 0 & 0 & 0 & 0 & 0 & - \\
\hline \multirow[t]{3}{*}{ Cell extract } & Normal (S.M.) & $1.4 \pm 0.1$ & $3.8 \pm 0.3$ & $4.6 \pm 0.2$ & $4.5 \pm 0.2$ & $8.2 \pm 0.4$ & $6.1 \pm 0.3$ \\
\hline & Normal (C.M.) & $1.0 \pm 0.5$ & $1.2 \pm 0.2$ & $2.1 \pm 0.3$ & $6.4 \pm 0.8$ & $5.1 \pm 0.4$ & - \\
\hline & Patient (R.S.) & $\mathbf{0}$ & 0 & 0 & 0 & 0.2 & - \\
\hline
\end{tabular}

- Enzyme activity is expressed as nanomoles of fatty acids released per minute. Values shown are mean \pm SEM of three dishes from each of the normal subjects and of two dishes from the lipoprotein lipase-deficient patient. Interassay variation was corrected for by including in each assay a bovine milk lipoprotein lipase standard that was stored at $-70^{\circ} \mathrm{C}(11)$.

serum that had not been heat inactivated. The dishes were maintained in a $37^{\circ} \mathrm{C}$ incubator with humidified $95 \%$ air/ $5 \% \mathrm{CO}_{2}$ and fed the same medium every $2-3 \mathrm{~d}$.

Lipoprotein lipase assay. Lipoprotein lipase in the incubation medium at each time point was measured after feeding cells with fresh medium $24 \mathrm{~h}$ earlier, e.g. day 7 values were obtained by changing the medium on day 6 and measuring the enzyme activity $1 \mathrm{~d}$ later. After removing the medium, the monocyte/macrophage layer was washed once with Krebs-Ringer phosphate (KRP) $)^{1}$ buffer at $37^{\circ} \mathrm{C}$, and $0.5 \mathrm{ml} \mathrm{KRP} \mathrm{buffer} \mathrm{containing} 25 \%$ (vol/vol) of serum and $50 \mu \mathrm{g} / \mathrm{ml}$ heparin was added to the dishes. The cells were then incubated for $30 \mathrm{~min}$ at $37^{\circ} \mathrm{C}$ for the measurement of heparin eluted lipoprotein lipase activity. At the end of this incubation period, the medium was removed, the cell layer was washed five times with KRP buffer and $1.25 \mathrm{ml}$ of a detergent solution $(0.2 \%$ (vol/vol) sodium deoxycholate, $0.008 \%$ Nonidet $P-40,50 \mu \mathrm{g} / \mathrm{ml}$ heparin, $10 \mathrm{mg} / \mathrm{ml}$ bovine serum albumin, and $0.25 \mathrm{M}$ sucrose in $0.22 \mathrm{M}$ Tris- $\mathrm{HCl}$ buffer, $\mathrm{pH}$ 8.5) was added to extract the cell layer. The cell extract was removed by scraping with a Teflon policeman and then was homogenized using a glass homogenizer. After centrifugation for $15 \mathrm{~min}$ at $12,000 \mathrm{~g}$, an aliquot was assayed for lipoprotein lipase. Pellets of freshly isolated monocytes were subjected to serum-heparin elution and detergent extractions by the procedures used for the cell layers, except that the KRP buffer washes were omitted.

To test whether serum stimulated the lipase activity present in the incubation medium, an aliquot of medium was subjected to affinity chromatography on a column $(0.5 \mathrm{ml})$ of heparin-Sepharose CL-6B at $4^{\circ} \mathrm{C}(10)$. After washing the column with $1.5 \mathrm{ml}$ of $0.5 \mathrm{M} \mathrm{NaCl} / 0.01 \mathrm{M}$ sodium phosphate (pH 7.5) 15\% (vol/vol) glycerol, the lipase activity was eluted with $1.5 \mathrm{ml}$ of $1.0 \mathrm{M} \mathrm{NaCl}$ in the same buffer. The eluted enzyme activity then was assayed in the presence and absence of $5 \%(\mathrm{vol} / \mathrm{vol})$ serum.

${ }^{1}$ Abbreviation used in this paper: KRP buffer, KrebsRinger phosphate buffer.
Lipoprotein lipase was assayed by a modification of previously described methods $(11,12)$ using an emulsion of radiolabeled triolein and lecithin as substrate. Adjustments were made such that the final assay mixture contained 10 $\mu \mathrm{g} / \mathrm{ml}$ heparin, $5 \mathrm{mg} / \mathrm{ml}$ glycerol-tri- $\left[{ }^{14} \mathrm{C}\right]$ oleate $(0.05 \mu \mathrm{Ci} /$ $\mathrm{mg} \mathrm{sp}$ act $)$, emulsified with lecithin $(0.6 \mathrm{mg} / \mathrm{ml})$, and activated with $5 \%$ (vol/vol) pooled human serum. In some experiments, serum was omitted from the assay mixture, or $\mathrm{NaCl}$ was added to yield an ionic strength of 1.0. Aliquots of culture medium, serum-heparin eluted enzyme, or cell extracts were incubated with the substrate for $60 \mathrm{~min}$ at $37^{\circ} \mathrm{C}$. The inclusion of detergent did not alter significantly the measured lipase activity. The liberated fatty acids were extracted by the method of Belfrage and Vaughan (13) and measured by liquid scintillation counting (Packard Tri-Carb, Packard Instrument Co., Downers Grove, Ill.). Enzyme activity was expressed as nanomoles of fatty acids released per minute.

\section{RESULTS}

To determine whether monocytes or monocyte-derived macrophages produce lipoprotein lipase, enzyme activity was determined in freshly isolated cells and after $1,4,7,14$, and $21 \mathrm{~d}$ in culture. In freshly isolated monocytes, lipoprotein lipase was detected in the cell extracts from both normal subjects and at low activity in the heparin-eluate from one (Table I). However, 1 $\mathrm{d}$ in culture was enough to increase the activity in the extract as well as to stimulate the release of activity into a heparin eluate and into the culture medium. Continued culture of the cells resulted in a progressive increase in all three fractions. Peak activities in the culture medium and the heparin eluate were seen after $7 \mathrm{~d}$ whereas maximal activity in the cell extract was observed after 7 and $14 \mathrm{~d}$, respectively in the two nor- 
TABLE II

Effect of Antiserum to Lipoprotein Lipase on Lipase Activity in Human Macrophage Cell Extracts

\begin{tabular}{lcc}
\hline \multirow{2}{*}{ Subject } & \multicolumn{2}{c}{ Preincubation additive } \\
\cline { 2 - 3 } & $\frac{\text { Normal rabbit serum }}{2}$ Lipase activity & \\
\cline { 2 - 3 } & \multicolumn{2}{c}{ Antiserum } \\
\cline { 2 - 2 } & 18.0 & 2.3 \\
Normal C.M. & 0.8 & 1.3 \\
Patient R.S. & 90.2 & 4.3 \\
Bovine milk lipase & \multicolumn{2}{c}{} \\
\hline
\end{tabular}

Culture dishes (day 7) were washed five times with KRP buffer after which the cell layers of three dishes from each subject were consecutively extracted with $1.25 \mathrm{ml}$ of detergent and processed as described in Methods. Aliquots of each cell extract or a 20,000fold diluted sample of purified bovine milk lipoprotein lipase (5 $\mathrm{mg} / \mathrm{ml}$ ) (10) were incubated at $4^{\circ} \mathrm{C}$ for $2 \mathrm{~h}$ with an equal volume of either normal rabbit serum or antiserum to bovine milk lipoprotein lipase before assay of enzyme activity.

mal subjects. Throughout the $21 \mathrm{~d}$ in culture the highest activities always were observed in the culture medium (Table I). By contrast, macrophages from a patient lacking lipoprotein lipase in postheparin plasma and adipose tissue failed to produce detectable lipoprotein lipase activity during $14 \mathrm{~d}$ in culture (Table I). A small amount of lipolytic activity occasionally observed in the cell extracts from this patient was not inhibited by preincubation with an antiserum to lipoprotein lipase (Table II), and is therefore a different enzyme or an assay artifact.

The lipase activity elaborated by the cells from the normal subjects was stimulated by the presence of serum and also was completely inhibited by high ionic strength (Table III). Furthermore, the lipase bound to
heparin-Sepharose in the presence of $0.5 \mathrm{M} \mathrm{NaCl}$ (Table III) and was almost completely inhibited by an antiserum to lipoprotein lipase (Table II). These characteristics establish that the measured enzyme activity indeed is lipoprotein lipase (14).

\section{DISCUSSION}

These studies show for the first time that human monocyte-derived macrophages synthesize and secrete lipoprotein lipase. Recent studies have shown that an established cell line of mouse ascites tumor origin secrete this enzyme, which was identified as lipoprotein lipase by its requirement for apoprotein $\mathrm{C}-\mathrm{II}$, a $\mathrm{pH}$ optimum of 8.2 , inhibition with $1 \mathrm{M} \mathrm{NaCl}$, tight binding to a heparin-Sepharose affinity column, and enhanced secretion by heparin (6). Lipoprotein lipase also was present in extracts of rabbit alveolar macrophages (6). The present study confirms that the enzyme present in and secreted by human monocyte/macrophages also is lipoprotein lipase. It is inhibited by high ionic strength $\mathrm{NaCl}$, requires serum for activation, binds to heparin-Sepharose, and is inhibited by an antiserum to lipoprotein lipase. Equally compelling is that cells derived from an individual with a well characterized primary deficiency of lipoprotein lipase (7) were unable to secrete the enzyme. The small amount of lipolytic activity that was occasionally detected in the cell extract from this patient is unlikely to be lipoprotein lipase, because an effective antibody against this enzyme failed to inhibit this lipolytic activity.

Because macrophages of three widely different origins produce lipoprotein lipase, it is likely that the enzyme is ubiquitous in this cell type. The physiological role of macrophage lipoprotein lipase remains to be established. It is possible that lipoprotein lipase

TABLE III

Effect of Serum and Ionic Strength on Lipase Activity from Cultured Human Macrophages ${ }^{\bullet}$

\begin{tabular}{|c|c|c|c|c|c|c|}
\hline \multirow{3}{*}{ Enzyme source } & \multicolumn{6}{|c|}{ Lipase activity } \\
\hline & \multicolumn{2}{|c|}{ +Serum, ionic strength, $0.16 !$} & \multicolumn{2}{|c|}{-Serum, ionic strength, $0.16 t$} & \multicolumn{2}{|c|}{ +Serum, ionic strength, 1.01} \\
\hline & $n \operatorname{mol} / \min / d i s h$ & $\%$ & $\mathrm{nmol} / \mathrm{min} / \mathrm{dish}$ & $\%$ & $n m o l / m i n / d i s h$ & $\%$ \\
\hline Culture medium & 55.6 & 100 & $-\$$ & $-\$$ & 0 & $\mathbf{0}$ \\
\hline Heparin eluate & 6.7 & 100 & $一^{\prime \prime}$ & - & $\mathbf{0}$ & 0 \\
\hline Cell extract & 3.9 & 100 & 0.4 & 10 & 0 & $\mathbf{0}$ \\
\hline
\end{tabular}

- The experiment was performed with cultures obtained from normal subject S.M., day 7.

$\ddagger$ Tris- $\mathrm{HCl}$ buffer contributed an ionic strength of 0.05 ; the remainder was $\mathrm{NaCl}$.

$\$$ The serum content of the culture medium contributed a serum concentration of $2 \%(\mathrm{vol} / \mathrm{vol})$ to the complete assay mixture, and thus decreased the effect of further serum additions. Therefore, an aliquot of medium $(3 \mathrm{ml})$ pooled from four dishes (normal subject C.M., day 12) was subjected to affinity chromatography on a heparin-Sepharose column (Methods). $80 \%$ of the lipase was recovered by elution with $1.5 \mathrm{ml}$ of $1.0 \mathrm{M} \mathrm{NaCl}$. The activity of the purified enzyme assayed without serum was only $7.6 \%$ of that obtained in the presence of a standard serum concentration $(5 \%, \mathrm{vol} / \mathrm{vol})$.

"Elution of cell layer with heparin in the absence of serum did not yield enough enzyme activity for testing of serum stimulation. 
hydrolyzes triglycerides to supply the cells with the energy required for synthesis of its multitude of products secreted after blood monocytes have been converted to tissue macrophages (3). Alternatively, lipoprotein lipase could participate in the scavenger function of these cells.

The finding that macrophages produce lipoprotein lipase is of particular interest because lipoprotein lipase has been previously identified in arterial atheromatous plaques (15), but not in normal artery. It is likely that macrophages are the source of this enzyme rather than endothelial cells, thus giving Zilversmit's hypothesis (5), i.e., that lipoprotein lipase may facilitate arterial wall lipid accumulation, a new perspective. Synthesis and secretion of lipoprotein lipase by macrophages could favor local accumulation of remnantlike particles in areas of endothelial denudation that could lead to accumulation of lipid in arterial wall cells and foam cell formation.

\section{ACKNOWLEDGMENTS}

The expert technical assistance of Martha Kimura, Steve Hashimoto, and Marty Jensen and skillful preparation of the manuscript by Sharon Kemp is gratefully acknowledged. The antibody to lipoprotein lipase was a gift from Drs. J. Huttunen, C. Ehnholm, and E. Nikkilä of University of Helsinki, Finland.

Supported in part by U. S. Public Health Service grants HL 18687, AM 02456, and AM 07247 and by grants from the Juvenile Diabetes Foundation (80R448) and the American Diabetes Association. Part of this work was performed at the University Hospital Clinical Research Center (RR-37).

\section{REFERENCES}

1. Goldstein, J. L., Y. K. Ho, S. K. Basu, and M. S. Brown. 1979. Binding site on macrophages that mediates uptake and degradation of acetylated low density lipoprotein, producing massive cholesterol deposition. Proc. Nat. Acad. Sci. U. S. A. 76: 333-337.
2. Fogelman, A. M., I. Shechter, J. Seager, M. Hokom, J. S. Child, and P. A. Edwards. 1980. Malondialdehyde alteration of low density lipoproteins leads to cholesteryl ester accumulation in human monocyte-macrophages. Proc. Nat. Acad. Sci. U. S. A. 70: 2214-2218.

3. Nathan, C. F., H. W. Murray, and Z. A. Cohn. 1980. The macrophage as an effector cell. N. Engl. J. Med. 303: 622-626.

4. Chait, A., and T. Mazzone. 1981. A human macrophage secretory product increases low density lipoprotein uptake by arterial smooth muscle cells. Clin. Res. 29: 493a.

5. Zilversmit, D. B. 1979. Atherogenesis: a postprandial phenomenon. Circulation. 3: 473-485.

6. Khoo, J. C., E. M. Mahoney, and J. L. Witztum. 1981. Secretion of lipoprotein lipase by macrophages in culture. J. Biol. Chem. 256: 7105-7108.

7. Brunzell, J. D., A. Chait, E. A. Nikkilä, C. Ehnholm, J. E. Huttunen, and G. Steiner. 1980. Heterogeneity of primary lipoprotein lipase deficiency. Metab. Clin. Exp. 29: 624-629.

8. Fogelman, A. M., J. Seager, M. Hokom, and P. A. Edwards. 1979. Separation of and cholesterol synthesis by human monocytes and lymphocytes. J. Lipid Res. 20: 379-388.

9. Johnson, W. D., B. Mei, and Z. A. Cohn. 1977. The separation, long-term cultivation, and maturation of the human monocyte. J. Exp. Med. 146: 1613-1626.

10. Iverius, P-H., and A-M. Östlund-Lindqvist. 1976. Lipoprotein lipase from bovine milk. Isolation procedure, chemical characterization, and molecular weight analysis. J. Biol. Chem. 251: 7791-7795.

11. Iverius, P-H., U. Lindahl, T. Egelrud, and T. Olivecrona. 1972. Effects of heparin on lipoprotein lipase from bovine milk. J. Biol. Chem. 247: 6610-6616.

12. Schwartz, R. S., and J. D. Brunzell. 1981. Increase of adipose tissue lipoprotein lipase activity with weight loss. J. Clin. Invest. 67: 1425-1430.

13. Belfrage, P., and M. Vaughan. 1969. Simple liquid-liquid partition system for isolation of labeled oleic acid from mixtures with glycerides. J. Lipid Res. 10: 341344.

14. Robinson, D. S. 1965. The clearing factor lipase activity of adipose tissue. Handb. Physiol. (Sect. 5, Adipose tissue): 295-299.

15. DiCorleto, P. G., and D. B. Zilversmit. 1975. Lipoprotein lipase activity in bovine aorta. Proc. Soc. Exp. Biol. Med. 148: 1101-1105. 